\title{
Criminality in the municipalities of the State of Rio de Janeiro: in search of its essence and its dynamics
}

Ademir Clemente 1

Leonel Toshio Clemente ${ }^{2}$

Artur Kendi Clemente ${ }^{3}$

1 Universidade Federal do Paraná / Programa de Pós-Graduação em Contabilidade, Curitiba / PR - Brazil

${ }^{2}$ Universidade Federal do Rio Grande do Sul / Departamento de Economia e Relações Internacionais, Porto Alegre / RS - Brazil

${ }^{3}$ Universidade Federal do Paraná / Departamento de Economia, Curitiba / PR - Brazil

This article seeks the essence and dynamics of the crime phenomenon in the municipalities of the State of Rio de Janeiro. The approach is statistical and econometric, using Principal Component Analysis and Granger Causality Analysis. The data obtained from the Public Security Institute of the State of Rio de Janeiro (ISP/RJ) comprise 47 variables and cover the period from 2003 to 2018. The hypothesis that the phenomenon of crime is integrated, complex, and dynamic, according to the Theory of Institutional Choice and the Theory of Broken Windows, was supported by the data. We identified four dimensions of criminality: Robbery, Theft, Crime against the Person, and Drug Crime. The results show that the municipalities have a moderate level of specialization in these dimensions of crime since the ordinal correlation is weak and is negative between the ranks in Robbery and Drug crimes. The results also show an intense network of interconnections between the dimensions of crime over time.

Keywords: crime; State of Rio de Janeiro; municipalities of the State of Rio de Janeiro; criminal statistics; crime dynamics.

\section{Criminalidade nos municípios do Estado do Rio de Janeiro: em busca da sua essência e da sua dinâmica}

Este artigo busca a essência e a dinâmica do fenômeno da criminalidade nos municípios do Estado do Rio de Janeiro. A abordagem é estatística e econométrica, usando Análise de Componentes Principais e Análise de Causalidade de Granger. Os dados obtidos junto ao Instituto de Segurança Pública do Estado do Rio de Janeiro (ISP/RJ) compreendem 47 variáveis e abrangem o período de 2003 a 2018. A hipótese de que o fenômeno da criminalidade é integrado, complexo e dinâmico, de acordo com a Teoria da Escolha Institucional e a Teoria das Janelas Quebradas, encontra suporte nos dados. Identificamos quatro dimensões da criminalidade: Roubo, Furto, Crimes Contra a Pessoa e Crimes Relacionados a Drogas. Os resultados mostram que os municípios apresentam um grau de especialização moderado nessas dimensões do crime, uma vez que a correlação ordinal é fraca e é negativa entre os postos em Roubo e Crimes Relacionados a Drogas. Os resultados também mostram uma intensa rede de interconexões entre as dimensões do crime ao longo do tempo.

Palavras-chave: crime; Estado do Rio de Janeiro; municípios do Estado do Rio de Janeiro; estatísticas criminais; dinâmica do crime.

\section{La criminalidad en los municipios del Estado de Rio de Janeiro: en busca de su esencia y su dinámica}

Este artículo busca la esencia y dinámica del fenómeno delictivo en los municipios del Estado de Río de Janeiro. El enfoque es estadístico y econométrico, utilizando el Análisis de Componentes Principales y Análisis el análisis de Causalidad de Granger. Los datos obtenidos del Instituto de Seguridad Pública del Estado de Río de Janeiro (ISP/RJ) comprenden 47 variables y cubren el período de 2003 a 2018. La hipótesis de que el fenómeno de la delincuencia es integrado, complejo y dinámico, siguiendo la Institutional Choice Theory y de lasla Broken Windows Theory, encuentran apoyo en los datos. Identificamos cuatro dimensiones del delito: Robo, Hurto, delitos contra la Persona y delitos relacionados con las Drogas. Los resultados muestran que los municipios tienen un grado moderado de especialización en estas dimensiones delictivas, ya que la correlación ordinal es débil y es negativa entre ordenaciones de Robo y Delitos Relacionados con Drogas. Los resultados también muestran una intensa red de interconexiones entre las dimensiones del crimen a lo largo del tiempo.

Palabras clave: crimen; Estado de Río de Janeiro; municipios del Estado de Río de Janeiro; estadísticas criminales; dinámica del crimen. 


\section{ACKNOWLEDGEMENTS}

We are particularly grateful to Professor Cesar das Neves for his teachings and friendship.

\section{INTRODUCTION}

Historically, crime presents two distinct meanings: in absolute monarchies, crime was an offense to the monarch, who was responsible for monitoring, judging, and punishing; but with the advent of republics, the State became an abstract entity, theoretically representing the interests of society, and crime became an offense to society. In republics, the State has the legislative, judicial and police functions (Foucault, 1987).

Brazilian society rapidly urbanized in the second half of the Twentieth Century, and the problem of urban crime and violence became critical, currently reaching around 60 thousand homicides a year. That is not all. The prison population has tripled since 2000 and currently stands at around 800,000 (Departamento Penitenciário Nacional [DEPEN], 2020).

The State of Rio de Janeiro, occupying just $0.5 \%$ of the national territory and concentrating 17 million inhabitants, about $8 \%$ of the country's population, occupies a prominent position in the scene of violence and crime. The 92 municipalities in Rio de Janeiro have a high degree of conurbation. The capital of the State of Rio de Janeiro, city with the same name, is the centre of the second largest metropolitan region in the country, comprising 22 municipalities and more than 13 million inhabitants. In addition, the State of Rio de Janeiro has the highest population density among all states, reaching around 400 inhabitants per square kilometre. Only the Federal District has a higher demographic density.

Chronic crime has provided its institutionalization as an advanced stage of crime, capable of imposing a set of rules of its own, rules that confront the law, and that gain recognition inside and outside criminal organizations, inside and outside prisons. Organized crime gains recognition from the population and high degree of institutionalization, operating entirely outside the law, according to its own criteria, rules, and standards.

Unfortunately, public security policy in Brazil and other countries has been based on violent repression and has been perceived as independent of other public policies. The existence of military police under the responsibility of the states allows for widespread violent repression. The adoption of ostensible and violent repression is associated with the militarization of the police. In this regard, Souza and Serra (2020) show that the military intervention of the Federal Government in the State of Rio de Janeiro reinforced the policy of violent repression.

Among security officials, prevails the belief that violent incursions into favelas and areas considered of high crime, causing death and fear, are capable of detaining criminals. However, the econometric study by Monteiro, Fagundes and Guerra (2020) for the State of Rio de Janeiro shows that the number of deaths resulting from police action rather than having a negative effect on crime indicators in these areas has a positive effect, although moderate.

As Cano and Duarte (2012, p. 59) point out, the militias and drug trafficking act similarly in search for legitimacy, offering protection, and coercing residents and intimidating them. In fact, protection and coercion are complementary to varying degrees, and what prevents the application of extreme terror is the possibility that residents will come to support a rival group. 
For the "war on crime" there is an enemy to be exterminated and given this objective the rules of citizenship and civility become irrelevant. The favela is considered a territory of non-citizenship, where there would be no innocents, because everyone who lives there would have made that choice. In addition, complicity would be proven by neighbourhood relations, kinship, etc. (Leite, 2012).

The situation in the State of Rio de Janeiro is an icon of the failure of public policies aimed at combating violence through violence. The official recognition of the critical situation in the State of Rio de Janeiro has already materialized in extreme heterodox measures to contain crime and violence. Recent examples are the creation of Pacifying Police Units (UPPs) and the federal intervention in the state public security.

Simple calculations can show the high social costs of the policies of repression and incarceration, policies clearly incapable of reducing crime. Worse yet, security officials show no signs of changing such public policies.

The central question of this article is: What is the essence and dynamics of the phenomenon of crime in the municipalities of the State of Rio de Janeiro?

The objective is to examine statistically and econometrically crime in the municipalities of the State of Rio de Janeiro. We seek, through statistical and econometric analysis, to identify the constitutive dimensions of the phenomenon and the way these dimensions are dynamically related, interacting and feeding back.

We chose the State of Rio de Janeiro due to its demographic density, its level of urbanization, the availability of data and, above all, for its critical situation in relation to criminality.

Considering the municipalities of the State of Rio de Janeiro as an object of study may contribute to an in-depth knowledge of criminality. Such knowledge is necessary to support innovative and effective public policies, probably appropriate to other regions in Brazil and abroad. After all, the phenomenon of crime requires careful analysis, capable of providing other bases for the formulation and implementation of public policies.

This article gains importance because the traditional way of fighting crime has not been effective; on the contrary, it increases stress, insecurity, and fear, in addition to having a prohibitive social cost, claiming many lives. The authorities seem to be content with the news about their actions of violent repression, instead of really worrying not only about the results of the media, but with the results in the medium and long term.

Noteworthy is the work that the Public Security Institute (ISP) develops. ISP publishes monthly statistics on dozens of variables related to crime in the municipalities of the State of Rio de Janeiro. The actual use of these data represents not only a valuable allocation of the resources applied to their production and dissemination, but also an opportunity to criticize them and, thus, provide opportunities for their improvement.

Undoubtedly, public authorities need to know the causes of criminality, its nature, and dynamics so that their actions cease to be topical, disordered, and ineffective, centred on the traditional war on crime. The confrontation based on violence has repercussions in the media, but it is ineffective and represents losses of human life and of property, that is, it implies an extremely high social cost.

The authorities' opinions and beliefs about the causes of crime, its nature, its dynamics, and ways of combating it, the appearance of short breath super-sheriffs and the generalized fiasco of State initiatives in the area make it urgent and important to carry out research works. Without understanding the causes of crime, government actions tend to be topical, superficial, and ineffective. 
In view of this, the analysis of the essence and dynamics of crime, based on hard data, can provide a reflection on the usual beliefs and practices, and offer the opportunity for the adoption of new concepts and more effective approaches.

This article contains, in addition to this introduction, four other sections: Theoretical framework, Methodological notes, Analysis, and Conclusion.

\section{THEORETICAL FRAMEWORK}

Theories dealing with crime fall into two categories: theories centred on the individual and theories centred on society, as summarized below.

\subsection{Lombrosian Theory}

The oldest theoretical approach seeks in individuals the explanation for socially reprehensible behaviour. In this line of thought, the physician Cesare Lombroso stands out.

Cesare Lombroso, in the book entitled The Delinquent Man, published in 1876, begins by observing violent behaviour in several species, such as animals that feed on others of the same species. Thus, he concludes that delinquency is present in Nature and is part of it. As for the human species, he sought in the formation of the skull the explanation for the delinquent behaviour (Lombroso, 2007).

The Lombroso's craniology had an intense repercussion in the intellectual and political classes and reflected in extensions that changed the focus for the races. Thus, not only delinquent behaviour, but also the willingness to work and the intellectual capability were associated with race.

In 1969, Arthur Jensen, professor of educational psychology, published an article in which he argues that blacks had a lower Intelligence Quotient (IQ) (Jensen, 1969). Since then, the issue has been controversial mainly because he did not consider control variables representative of individuals' socioeconomic conditions.

Lombroso still reverberates in the form of prejudice towards Afro-descendants, Indians, and people with dark skin in general. The Lombrosian Theory made countless adherents in Brazil. Once it became a republic, in 1989, the intellectuals and politicians chose the whitening of the population as the national objective, considered a condition for achieving progress. The search for European immigrants and, later, for Asians, was part of that strategy (Maia \& Zamora, 2018; Silva, 2017).

According to the Lombrosian Theory, individuals are more prone to crime due to innate characteristics that make them more influential and less able to assess the consequences of their actions. However, would not they become more prone to crime because they come from unstructured families? Families more prone to violence? Because their homes and food were poor? Because they attended poor quality schools or did not attend schools, etc.?

Indeed, considering that individual-centred explanations of criminality are of any value is a real nonsense with dire consequences. Those explanations, in addition to not having obtained scientific proof, affront human dignity as a fundamental value and lead to policies of segregation and hatred. In short, Lombrosian Theory and its derivations should not take place in democratic societies, where citizenship must be a fundamental value. 


\subsection{The Institutional Choice Theory}

Institutions are sets of political, economic, and cultural rules. Institutions constitute the environment in which individuals make choices and act. In this way, institutions and the institutional environment condition and guide agents in society. In turn, the institutional environment does not constitute a solid and frozen mosaic, it modifies over time by the dynamics of society, with the emergence of new values and patterns (Collier, 2002). Thus, the institutional environment that constitutes the external world influences the agents' internal world, as it conditions and limits their choices.

Rules guide agents and define their roles and areas of operation, resulting in standards of conduct. Society recognizes and validates those standards, giving place to a certain structure and functioning. Changes in rules redefine the institutions and roles of agents, as well as relationships between them. Individual agents and society influence each other in a dynamic and continuous process over time (Onuf, 1997 as cited in Collier, 2002).

From the point of view of the Theory of Institutional Choice, the institutional environment of society exerts influence on criminality. A clear institutional environment, clear rules, with high acceptance and respectability, acts as a social brake to inhibit criminal actions. On the other hand, a confusing institutional environment, conflicting rules, not always clear and well known, with little acceptance and respectability, is a fertile ground for criminal actions.

Judge, McNatt and $\mathrm{Xu}$ (2011) analysing the causes of corruption, argue that it results from institutional choices. The external world, constituted by the institutional structure, influences the internal world of the decision-making agent. The expected benefits and costs of each decision are also located in the outside world. The behaviour of agents, over time, shapes the institutional structure in which agents operate, constituting a circular process. Thus, corruption institutionalizes as it becomes a widespread behaviour, and its disapproval decreases or disappears. In other words, corruption institutionalizes, as it becomes the rule.

The Institutional Choice Theory can apply to the analysis of crime. This theory becomes applicable to the extent that society starts to live with a parallel institutional structure that imposes its own rules, in which the State is absent. In this parallel world, the costs and benefits of agents' decisions and actions are radically different from the costs and benefits of the world in which state institutions prevail. To make matters worse, the separation between the two institutional systems is nebulous and uncertain, subject to violence by both the State and the criminal world. Ironically, State and crime have methods remarkably similar; both use violence and cause a high rate of homicides.

In deciding whether to commit crime or not, the current level of crime has an influence on individuals. Moral disapproval is certainly much more painful and significant when the offender feels alone in the face of widespread condemnation for offending moral standards. However, if criminal action has already become commonplace, not only will the delinquent not feel alone and isolated, instead of disapproval, he may receive approval. In other words, as crime becomes institutionalized, conventional morality loses its meaning and the moral framework becomes that of the world of crime, with its rules and sanctions.

The inadequate and pyrotechnic presence of the State, centred on violent repression, facilitates the process described above and points to a cumulative effect in which a higher level of criminality and its dissemination constitute permission and incentive to new criminal actions. The result is the 
expansion of the social space controlled by institutionalized crime and the increasingly ingrained withdrawal from the conventional institutional structure of the State and its legal apparatus.

State institutions generally take the form of law, which includes sanctions for non-compliance with their dictates. However, criminality rules are informal and the degree of discretion in their application is highly variable. Therefore, from the point of view of the Institutional Choice Theory, crime is a complex and integrated phenomenon, subject to its own institutions, flexible and changeable in space and time. In view of the Institutional Choice Theory, the classification and segmentation of criminal actions and the design of public policies aimed specifically at a particular type of crime will never succeed.

Thus, the idea of a delinquent individual acting autonomously and independently, which could evoke the Lombrosian paradigm, should be replaced by the broader conceptions of weak State institutions, absent State, sick society, criminal organization, institutionalization of crime and so on.

\subsection{The Broken Windows Theory}

In the field of social psychology, the Theory of Broken Windows, developed in the United States, stands out. Evidence from experiments shows that signs of disorganization and abandonment encourage criminal actions.

Two cars in good conditions were abandoned, one in a violent and disorganized neighbourhood, the other in a safe neighbourhood, with an exceptionally low crime rate. After a week, the car abandoned in the violent neighbourhood resulted destroyed, while the one abandoned in the quiet neighbourhood remained intact. Then, one window of the intact car was intentionally broken. After a week, the second car also resulted destroyed (Kelling \& Wilson, 1982).

The Broken Windows Theory served as the basis for the Zero Tolerance Policy, initially implemented on the New York subway, recognized for its high level of violence and vandalism. Relentless actions from authorities systematically restricted small transgressions, strictly within the rules, and the good results were impressive. A few years later, the zero-tolerance policy was extended to all of New York City, proving that admitting wrongdoings, small or large, forms an environment conducive to delinquency (Brasil 247, 2020).

We found important similarities with the Institutional Choice Theory. We could argue that the intact car left in the violent neighbourhood already had, in fact, a broken window that was invisible simply because it was there unattended. In other words, the broken window would be a perception of the institutional environment and, therefore, the window that was intentionally broken in the organized neighbourhood was already present in the car left unattended in the violent neighbourhood. In fact, the intact car left unattended in the violent neighbourhood had a broken window and was subject to destruction. A broken window is not necessary for the perception of disorder in the violent neighbourhood, but it fulfils its role in the organized neighbourhood, as it signals a degraded institutional environment.

Considering these theories in the Brazilian context, we realize that they apply to the so-called "jeitinho", culturally rooted. The "jeitinho" is the social acceptance of small transgressions that are supposed to do no harm to anyone. The "jeitinho" solves a specific situation; it benefits a person or a group and requires smartness. It generally harms no one in particular, and people neglect its negative effect, although it is obviously harmful to society (Wachelke \& Prado, 2017). 
These small and institutionalized transgressions, represented by the "jeitinho", are a favourable factor to an environment permissive to transgressions in general, according to the Theory of Institutional Choice; and represent the Broken Window, according to the Theory of Broken Windows. This highlights the complexity involved in the formulation and implementation of public policies designed to contain crime, since the authorities must consider the cultural dimension involved.

Both theories are behavioural, dealing with delinquent behaviour in a certain environment, an environment that results from the complex interaction between social, economic, cultural, and political factors and which feeds, reinforces and deepens with the behaviour of individuals, developing a circular process. Therefore, we realize that the decision to commit crimes is complex, multifaceted, and multicausal, receiving influences from a variety of factors. The result is a certain level of institutionalization of criminality, which progresses as the observation of the rules of morality loosens and moves away, opening space for the imposition of the rules of delinquency.

\subsection{Hypothesis}

Certainly, the phenomenon of criminality results from the interaction of many factors. Social, cultural, economic, and political factors interact and create the conditions that result in a certain level of crime. The Institutional Choice Theory, as pointed out, privileges the institutional environment and existing structures as limiting or allowing criminal activities.

In turn, the Theory of Broken Windows favours the perception of the environment as the main factor in the decision to delinquent. The perception that moral principles no longer prevail or that the observance of legal dictates is not necessary would constitute permission or invitation to transgression.

With these theories in mind, we formulate the following hypothesis: Crime in the municipalities of the State of Rio de Janeiro is a complex, integrated and dynamic social phenomenon.

\section{METHODOLOGICAL NOTES}

The crime statistics for the municipalities of the State of Rio de Janeiro come from the website of the Public Security Institute (ISP). We totalled the monthly data to obtain annual data for the period from 2003 to 2018 .

Initially, we observed that 13 of the 92 municipalities in the State of Rio de Janeiro had many missing data and we excluded them from the sample. Another three municipalities presented crime statistics in conjunction with another municipality. Therefore, we ended up with 76 observational units.

Additional analysis showed the need to exclude the municipality of Comendador Levy Gasparian, whose crime statistics per thousand inhabitants reached about 10 times the average for the state of Rio de Janeiro. In addition, we observed that the municipality of Campos dos Goytacazes also clashes significantly with the rest of the sample in relation to socioeconomic variables, representing an unequivocal extreme point, and we excluded it from the sample. Box 1 summarizes this information. 
RAP $\mid$ Criminality in the municipalities of the State of Rio de Janeiro: in search of its essence and its dynamics

\begin{tabular}{rlll} 
& EXCLUDED MUNICIPALITIES & & CONSIDERED TOGETHER \\
\hline 1 & Areal & 1 & Cordeiro and Macuco \\
2 & Arraial do Cabo & & \\
3 & Campos dos Goytacazes & & \\
4 & Carapebus & & \\
5 & Cardoso Moreira & & \\
6 & Comendador Levy Gasparian & & \\
7 & Guapimirim & 2 & Porto Real and Quatis \\
8 & Italva & & \\
9 & Paty do Alferes & & \\
10 & Pinheiral & & \\
11 & Quissamã & 3 & Santo Antônio de Pádua and \\
12 & São José de Ubá & & Aperibé \\
13 & Tanguá & & \\
14 & Três Rios & Varre-Sai & \\
15 & & \\
\hline
\end{tabular}

Source: Elaborated by the authors.

As a result, 74 observational units remained in the sample, 71 municipalities and 3 observations with 2 municipalities each. Considering that the period comprises 16 years, we ended with a maximum 1,184 observations.

We specify the variables obtained from the ISP website in Box 2. Some variables showed many zeros in the municipalities' annual totals. Therefore, we considered, alternatively, two databases: one containing all available variables and the other, only the most frequently recorded crimes, understood as those that present at least half of the annual totals as non-zero values.

\section{BOX 2 VARIABLES REPRESENTING CRIME}

\begin{tabular}{lll}
\multicolumn{2}{c}{ VARIABLE } & \multicolumn{2}{c}{ SPECIFICATION } \\
1 & Int_murder* & Intentional murder \\
2 & Bodly_inj_death & Bodily injury followed by death \\
3 & Robbery_death* & Robbery followed by the victim's death \\
4 & Death_police* & Death by police intervention \\
\hline
\end{tabular}


RAP | Criminality in the municipalities of the State of Rio de Janeiro: in search of its essence and its dynamics

\begin{tabular}{|c|c|c|}
\hline & VARIABLE & SPECIFICATION \\
\hline 5 & Attempted_hom* & Attempted homicide \\
\hline 6 & Int_bodily_injury* & Intentional bodily injury \\
\hline 7 & Rape $^{\star}$ & Rape \\
\hline 8 & Guilty_homicide* & Guilty homicide (traffic) \\
\hline 9 & Guilty_bodily_injury* & Guilty bodily injury (traffic) \\
\hline 10 & Robbery_commerc* & Robbery of commercial establishments \\
\hline 11 & Robbery_residence* & Robbery of residence \\
\hline 12 & Vehicle_robbery* & Vehicle robbery \\
\hline 13 & Cargo_robbery ${ }^{\star}$ & Cargo robbery \\
\hline 14 & Robbery_passers-by ${ }^{*}$ & Robbery of passers-by \\
\hline 15 & Robbery_bus* & Robbery inside a bus \\
\hline 16 & Bank_robbery & Bank robbery \\
\hline 17 & ATM_robbery & ATM robbery \\
\hline 18 & Cell_phone_robbery ${ }^{\star}$ & Cell phone robbery \\
\hline 19 & Robbery_withdraw_bank & Robbery with driving victim to withdraw from bank \\
\hline 20 & Robbery_after_withdraw* & Robbery after victim withdraws money from a bank \\
\hline 21 & Bicycle_robbery & Bicycle robbery \\
\hline 22 & Other_robberies* & Other robberies \\
\hline 23 & Vehicle_theft ${ }^{*}$ & Vehicle theft \\
\hline 24 & Theft_passers-by* & Theft applied to passers-by \\
\hline 25 & Theft_inside_bus* & Theft inside bus \\
\hline 26 & Cell_phone_theft ${ }^{\star}$ & Cell phone theft \\
\hline 27 & Bicycle_theft & Bicycle theft \\
\hline 28 & Other_thefts ${ }^{*}$ & Other thefts \\
\hline 29 & Kidnapping & Kidnapping \\
\hline 30 & Extortion ${ }^{\star}$ & Extortion \\
\hline 31 & Extortion_depriv_liberty & Extortion with momentary deprivation of liberty \\
\hline 32 & Swindle* & Swindle \\
\hline 33 & Seizure_drugs ${ }^{*}$ & Seizure of drugs \\
\hline 34 & Possession_drugs* & Possession of drugs \\
\hline 35 & Drug_trafficking* & Drug trafficking \\
\hline 36 & Drugs_without_author* & Seizure of drugs without author \\
\hline 37 & Vehicle_recovery & Vehicle recovery \\
\hline 38 & Detention_Flagrant & Detention at Flagrant \\
\hline
\end{tabular}




\begin{tabular}{lll}
\multicolumn{2}{c}{ VARIABLE } & \multicolumn{1}{c}{ SPECIFICATION } \\
39 & Teenager_Apprehension & Teenager Apprehension \\
40 & Arrest_warrant & Fulfilment of the arrest warrant \\
41 & Search_seizure_warrant & Fulfilment of the search and seizure warrant \\
42 & Threat* & Threat \\
43 & Missing_person* & Missing people \\
44 & Corpse_encounter * & Corpse Encounter \\
45 & Human_skulls_found & Human skulls found \\
46 & Military-policemen-killed & Military policemen killed in service \\
47 & Civilian_police_officers_killed & Civilian police officers killed at work
\end{tabular}

Note: ${ }^{\star}$ Most frequent crimes, with at least half of the annual municipal records not null. Source: ISP/RJ (Retrieved from http://www.ispdados.rj.gov.br/Notas.html).

In fact, 16 of the 47 crime-related variables had at least half of the annual municipal records equal to zero. Thus, the subset of variables that represent the most frequent crimes, which we name simply "frequent" from now on, comprises 31 variables.

\subsection{Hypothesis testing procedures}

Initially, we annualized the crime statistics published as monthly ones. Then, we divided the annual totals by the resident population in each municipality (Instituto Brasileiro de Geografia e Estatística [IBGE], 2019) to obtain coefficients per thousand inhabitants.

We found, then, that it was convenient to express the ample set of criminal variables provided by the ISP in a smaller number of dimensions. For that purpose, we employed the Principal Component Analysis (PCA).

As we expressed all the crime data as coefficients per thousand inhabitants, that is, using a single unit of measurement, we calculated the principal components based on the covariance matrix.

We adopted the Varimax orthogonal rotation to privilege the concepts brought by the original variables, and to obtain statistically unrelated dimensions. This type of axis rotation is suitable when the concepts associated with the variables are well determined, as is the case (Clemente, 1989; Hair, 2009).

In addition to the PCA, we carried out a Causality Analysis in the sense of Granger, or a GrangerCausality Analysis, seeking to make explicit the intertemporal effects between the dimensions of crime. We highlight that the Granger Causality Test does not verify the causal relationship between two variables; it only seeks to determine whether the past values of one variable contribute to predict the present value of another one. When this occurs, the first variable is a Granger-cause for the second one (Baltagi, 2011; Gujarati, 2007; LeSage, 1999). 


\section{ANALISYS}

In this section, we employ Principal Components Analysis and Granger-Causality Analysis.

\subsection{Principal Components Analysis (PCA)}

In Table 1, we show the results of the PCA for all crime rates per thousand inhabitants and for the subset of frequent crimes, which have less than half of the annual records equal to zero.

\section{TABLE $1 \quad$ PRINCIPAL COMPONENTS OF CRIME PER THOUSAND INHABITANTS}

\begin{tabular}{ccccc} 
COMPONENT & \multicolumn{2}{c}{ ALL CRIMES } & \multicolumn{2}{c}{ FREQUENT CRIMES } \\
\hline $\mathbf{1}$ & \% OF VARIANCE & ACCUMULATED & \% OF VARIANCE & ACCUMULATED \\
\hline $\mathbf{2}$ & 38.9 & & 40.6 & \\
$\mathbf{3}$ & 31.3 & 70.2 & 32.7 & 73.3 \\
$\mathbf{4}$ & 12.2 & 82.4 & 12.1 & 85.4 \\
& 6.0 & 88.4 & 6.3 & 91.7 \\
\hline
\end{tabular}

Source: Elaborated by the authors.

As stated before, we excluded 16 variables in the analysis of frequent crimes, because they present more than half of the annual municipal totals equal to zero. Those null figures may result from real rarity of a specific crime or from sub notification and underreporting. Despite this, the similarities between the results of the restricted PCA and the broad PCA are striking.

In the two analyses, the first four dimensions are capable of synthesizing about $90 \%$ of the information contained in the original variables. Disregarding less frequently registered crimes, this percentage rises from $88 \%$ to $92 \%$, probably due to underreporting and lack of notification of less serious crimes.

Table 2 presents the compositions of the first four Principal Components of the restricted analysis.

TABLE 2 LOADS OF THE FIRST FOUR PRINCIPAL COMPONENTS FOR FREQUENT CRIMES

\begin{tabular}{lllccc} 
& \multicolumn{1}{r}{ VARIABLES } & \multicolumn{4}{c}{ COMPONENTS* } \\
\hline 1 & Int_murder & 1 & 2 & 3 & 4 \\
\hline 2 & Robbery_death & 0.306 & 0.416 & \\
3 & Death_police & 0.149 & 0.153 & & -0.127 \\
4 & Attempted_hom & 0.533 & & & \\
\hline
\end{tabular}


RAP | Criminality in the municipalities of the State of Rio de Janeiro: in search of its essence and its dynamics

\begin{tabular}{|c|c|c|c|c|c|}
\hline \multirow{2}{*}{\multicolumn{2}{|c|}{ VARIABLES }} & \multicolumn{4}{|c|}{ COMPONENTS* } \\
\hline & & 1 & 2 & 3 & 4 \\
\hline 5 & Int_bodily_injury & -0.211 & 0.210 & & 0.905 \\
\hline 6 & Rape & & 0.132 & & 0.275 \\
\hline 7 & Guilty_homicide & -0.218 & 0.195 & & \\
\hline 8 & Guilty_bodily_injury & & 0.530 & -0.112 & 0.337 \\
\hline 9 & Robbery_commerc & 0.534 & 0.473 & & \\
\hline 10 & Robbery_residence & & 0.617 & & 0.159 \\
\hline 11 & Vehicle_robbery & 0.916 & & & \\
\hline 12 & Cargo_robbery & 0.499 & & & \\
\hline 13 & Robbery_passers-by & 0.983 & 0.112 & & \\
\hline 14 & Robbery_bus & 0.757 & & & \\
\hline 15 & Cell_phone_robbery & 0.847 & & & \\
\hline 16 & Robbery_after_withdraw & 0.550 & 0.121 & & \\
\hline 17 & Other_robberies & 0.688 & 0.303 & & \\
\hline 18 & Vehicle_theft & 0.418 & 0.559 & & \\
\hline 19 & Theft_passers-by & 0.688 & 0.349 & & \\
\hline 20 & Theft_inside_bus & 0.620 & 0.290 & & \\
\hline 21 & Cell_phone_theft & 0.276 & 0.459 & & 0.123 \\
\hline 22 & 0ther_thefts & & 0.924 & & 0.357 \\
\hline 23 & Extortion & 0.180 & 0.288 & 0.134 & 0.224 \\
\hline 24 & Swindle & 0.492 & 0.443 & & 0.150 \\
\hline 25 & Seizure_drugs & & & 0.987 & 0.116 \\
\hline 26 & Possession_drugs & & & 0.984 & \\
\hline 27 & Drug_trafficking & & & 0.447 & \\
\hline 28 & Drugs_without_author & & & 0.216 & \\
\hline 29 & Threat & -0.163 & 0.237 & 0.117 & 0.888 \\
\hline 30 & Missing_people & 0.280 & 0.279 & & 0.305 \\
\hline 31 & Corpse_encounter & -0.215 & 0.150 & & 0.187 \\
\hline
\end{tabular}

Note: * Only loads whose absolute value is greater than 0.1 .

Source: Elaborated by the authors.

According to the estimated loads, we can identify the four dimensions as follows:

- The first dimension is Robbery, and we associate it with the variable Robbery_passers-by;

- The second dimension is Theft, and we associate it with the variable Other_thefts; 
- The third dimension is Drugs, and we associate it with the variable Seizure_drugs;

- The fourth dimension is Offense to the Person, and we associate it with the variable Int_bodily_ injury.

Therefore, the four dimensions identified are Robbery, Theft, Drugs and Person. To confirm the previous results, we perform a PCA involving all variables, as shown in Table 3.

\section{TABLE $3 \quad$ LOADS OF THE FIRST FOUR PRINCIPAL COMPONENTS FOR ALL CRIMES}

\begin{tabular}{|c|c|c|c|c|c|}
\hline \multirow{2}{*}{\multicolumn{2}{|c|}{ VARIABLES }} & \multicolumn{4}{|c|}{ COMPONENTS* } \\
\hline & & 1 & 2 & 3 & 4 \\
\hline 1 & Int_murder & 0.414 & & 0.319 & \\
\hline 2 & Bodly_inj_death & & & & \\
\hline 3 & Robbery_death & 0.189 & & 0.107 & \\
\hline 4 & Death_police & 0.537 & & -0.107 & \\
\hline 5 & Attempted_hom & 0.228 & 0.229 & 0.266 & \\
\hline 6 & Int_bodily_injury & -0.177 & & 0.304 & 0.886 \\
\hline 7 & Rape & & 0.114 & 0.139 & 0.260 \\
\hline 8 & Guilty_homicide & -0.151 & & 0.251 & \\
\hline 9 & Guilty_bodily_injury & & & 0.555 & 0.313 \\
\hline 10 & Robbery_commerc & 0.636 & 0.112 & 0.304 & \\
\hline 11 & Robbery_residence & 0.177 & & 0.592 & 0.145 \\
\hline 12 & Vehicle_robbery & 0.900 & & -0.213 & \\
\hline 13 & Cargo_robbery & 0.480 & & -0.182 & \\
\hline 14 & Robbery_passers-by & 0.973 & & -0.162 & \\
\hline 15 & Robbery_bus & 0.760 & & -0.120 & \\
\hline 16 & Bank_robbery & & & & \\
\hline 17 & ATM_robbery & 0.214 & & 0.113 & \\
\hline 18 & Cell_phone_robbery & 0.834 & & -0.177 & \\
\hline 19 & Robbery_withdraw_bank & 0.392 & & 0.119 & \\
\hline 20 & Robbery_after_withdraw & 0.563 & & & \\
\hline 21 & Bicycle_robbery & 0.184 & & & \\
\hline 22 & Other_robberies & 0.749 & & & \\
\hline 23 & Vehicle_theft & 0.555 & & 0.427 & \\
\hline 24 & Theft_passers-by & 0.749 & 0.115 & 0.146 & \\
\hline
\end{tabular}




\begin{tabular}{|c|c|c|c|c|c|}
\hline & MPIADI ГC & & & ENTS* & \\
\hline & VAKIABLLES & 1 & 2 & 3 & 4 \\
\hline 25 & Theft_inside_bus & 0.671 & & 0.109 & \\
\hline 26 & Cell_phone_theft & 0.386 & 0.141 & 0.369 & 0.116 \\
\hline 27 & Bicycle_theft & & 0.188 & & \\
\hline 28 & Other_thefts & 0.168 & 0.146 & 0.916 & 0.325 \\
\hline 29 & Kidnapping & & & & \\
\hline 30 & Extortion & 0.233 & 0.156 & 0.231 & 0.224 \\
\hline 31 & Extortion_depriv_liberty & 0.223 & & & \\
\hline 32 & Swindle & 0.587 & 0.168 & 0.298 & 0.147 \\
\hline 33 & Seizure_drugs & -0.146 & 0.972 & & 0.154 \\
\hline 34 & Possession_drugs & -0.150 & 0.963 & -0.109 & 0.138 \\
\hline 35 & Drug_trafficking & & 0.492 & & \\
\hline 36 & Drugs_without_author & & 0.235 & & \\
\hline 37 & Vehicle_recovery & 0.773 & & 0.101 & \\
\hline 38 & Detention_Flagrant & 0.122 & 0.513 & & \\
\hline 39 & Teenager_Apprehension & 0.398 & 0.343 & & \\
\hline 40 & Arrest_warrant & & 0.289 & & \\
\hline 41 & Search_seizure_warrant & & 0.403 & & \\
\hline 42 & Threat & -0.131 & & 0.311 & 0.869 \\
\hline 43 & Missing_people & 0.336 & & 0.208 & 0.309 \\
\hline 44 & Corpse_encounter & -0.167 & & 0.214 & 0.171 \\
\hline 45 & Human_skulls_found & & & 0.220 & \\
\hline 46 & Military-policemen-killed & & & & \\
\hline 47 & Civilian_police_officers_killed & & & & \\
\hline
\end{tabular}

Note: ${ }^{\star}$ Only loads whose absolute value is greater than 0.1 .

Source: Elaborated by the authors.

The similarity between the results of the two analyses is evident. In addition, we note that no variable omitted in the PCA from the frequent records, Table 2, reaches expressiveness in the most comprehensive analysis, Table 3. In brief, the fact that the same four dimensions arise in both analyses, with only an inversion in the order involving the second and the third dimensions, is remarkable.

These results confirm the existence of four dimensions and indicate the convenience of prioritizing the restricted PCA due to the probable underreporting of crimes with many zeros in the municipal annual totals.

Table 4 refers to frequent crimes and contains only loads greater than 0.3 that are present in more than one dimension. 
RAP $\mid$ Criminality in the municipalities of the State of Rio de Janeiro: in search of its essence and its dynamics

\section{TABLE 4 LOADS GREATER THAN 0.3 IN MORE THAN ONE COMPONENT, FREQUENT CRIMES}

\begin{tabular}{lcccc} 
& & \multicolumn{2}{c}{ DIMENSIONS } \\
\multicolumn{1}{c}{ VARIABLES } & ROBBERY & THEFT & DRUGS & PERSON \\
\hline Int_murder & 0.306 & 0.416 & \\
Guilty_bodily_injury & & 0.530 & 0.337 \\
Robbery_commerc & 0.534 & 0.473 & \\
Other_robberies & 0.688 & 0.303 & \\
Vehicle_theft & 0.418 & 0.559 & \\
Theft_passers-by & 0.688 & 0.349 & \\
Other_thefts & & 0.924 & \\
Swindle & 0.492 & 0.443 & \\
\hline
\end{tabular}

Source: Elaborated by the authors.

Table 5 shows the results of the PCA involving all criminal records.

\section{TABLE 5 LOADS GREATER THAN 0.3 IN MORE THAN ONE COMPONENT, ALL CRIMES}

\begin{tabular}{lcccc} 
& & & DIMENSIONS \\
VARIABLES & ROBBERY & THEFT & DRUGS & PERSON \\
\hline Int_murder & 0.414 & 0.319 & \\
Int_bodily_injury & & 0.304 & 0.886 \\
Guilty_bodily_injury & & 0.555 & 0.313 \\
Robbery_commerc & 0.636 & 0.304 & \\
Vehicle_theft & 0.555 & 0.427 & \\
Cell_phone_theft & 0.386 & 0.369 & \\
Other_thefts & & 0.916 & \\
Teenager_Apprehension & 0.398 & & 0.343 \\
Threat & & 0.311 & \\
\hline Missing_people & 0.336 & & 0.869 \\
\hline
\end{tabular}

Source: Elaborated by the authors.

Tables 4 and 5 show that variables well identified with concepts, considered a priori as having distinct nature, present significant loads in more than one dimension, evidencing that the criminality phenomenon is intertwined. 
We observed that, having adopted the Varimax Rotation to privilege the well-established a priori concepts that the original variables represent; the obtained crime dimensions do not clearly separate from one another. The Robbery and Theft dimensions strongly base on the same variables. The imbrication of the Person dimension with the two mentioned above is also not negligible. Only the Drugs dimension is predominantly independent. These results demonstrate that crime escapes the traditional segmentation.

The results of the PCA are favourable to the hypothesis that crime is a complex and integrated phenomenon, corroborating the Theory of Institutional Choice and the Theory of Broken Windows, as it is not statistically possible to characterize the dimensions of crime separately.

\subsection{Crime in the Municipalities of the State of Rio de Janeiro}

Table 6 shows the four most populous municipalities in the State of Rio de Janeiro, totalling almost 10 million people, and accounting for more than half of the state population.

\section{TABLE $6 \quad$ MOST POPULOUS MUNICIPALITIES IN THE STATE OF RIO DE JANEIRO}

\begin{tabular}{lcc}
\hline MUNICIPALITY & POPULATION IN 2018 & \% OF THE STATE \\
\hline Rio de Janeiro & $6,688,927$ & 38.9 \\
São Gonçalo & $1,077,687$ & 6.3 \\
Duque de Caxias & 914,383 & 5.3 \\
Nova Iguaçu & 818,875 & 4.8 \\
Total & $9,499,872$ & 55.2
\end{tabular}

Source: IBGE (2019).

Table 7 shows the average number of crime occurrences per thousand inhabitants of the four dimensions of crime for the most populous municipalities, considering the entire period surveyed.

TABLE 7 CRIMINAL OCCURRENCES RECORDED PER THOUSAND INHABITANTS IN THE MAIN MUNICIPALITIES

\begin{tabular}{|c|c|c|c|c|}
\hline MUNICIPALITY & ROBBERY & THEFT & DRUGS & PERSON \\
\hline Rio de Janeiro & 5.30 & 7.04 & 0.89 & 4.69 \\
\hline São Gonçalo & 5.04 & 3.33 & 0.63 & 3.85 \\
\hline Duque de Caxias & 5.12 & 3.53 & 0.60 & 4.91 \\
\hline Nova Iguaçu & 4.20 & 3.06 & 0.40 & 4.45 \\
\hline
\end{tabular}

Source: Elaborated by the authors. 
The municipality of Rio de Janeiro presents higher averages in three dimensions: Robbery, Theft and Drugs. In relation to crime against the Person, the capital city ranks second, just below Duque de Caxias. In addition, the average of the Theft dimension in the state capital reaches double the averages presented by the other main municipalities. Of course, the most populous municipality, with about a third of the state's population, also stands out in relation to crime.

Graph 1 shows the municipalities in the state of Rio de Janeiro that are above the average robbery rate per thousand inhabitants per year, over the analysed period. The highest coefficient, observed in Nilópolis, stands out from the rest. Niterói, Rio de Janeiro, Duque de Caxias, São Gonçalo, Mesquita, São João do Meriti, and Nova Iguaçu also stand out.

\section{GRAPH 1 MUNICIPALITIES OF THE STATE OF RIO DE JANEIRO WITH ROBBERY ABOVE AVERAGE}

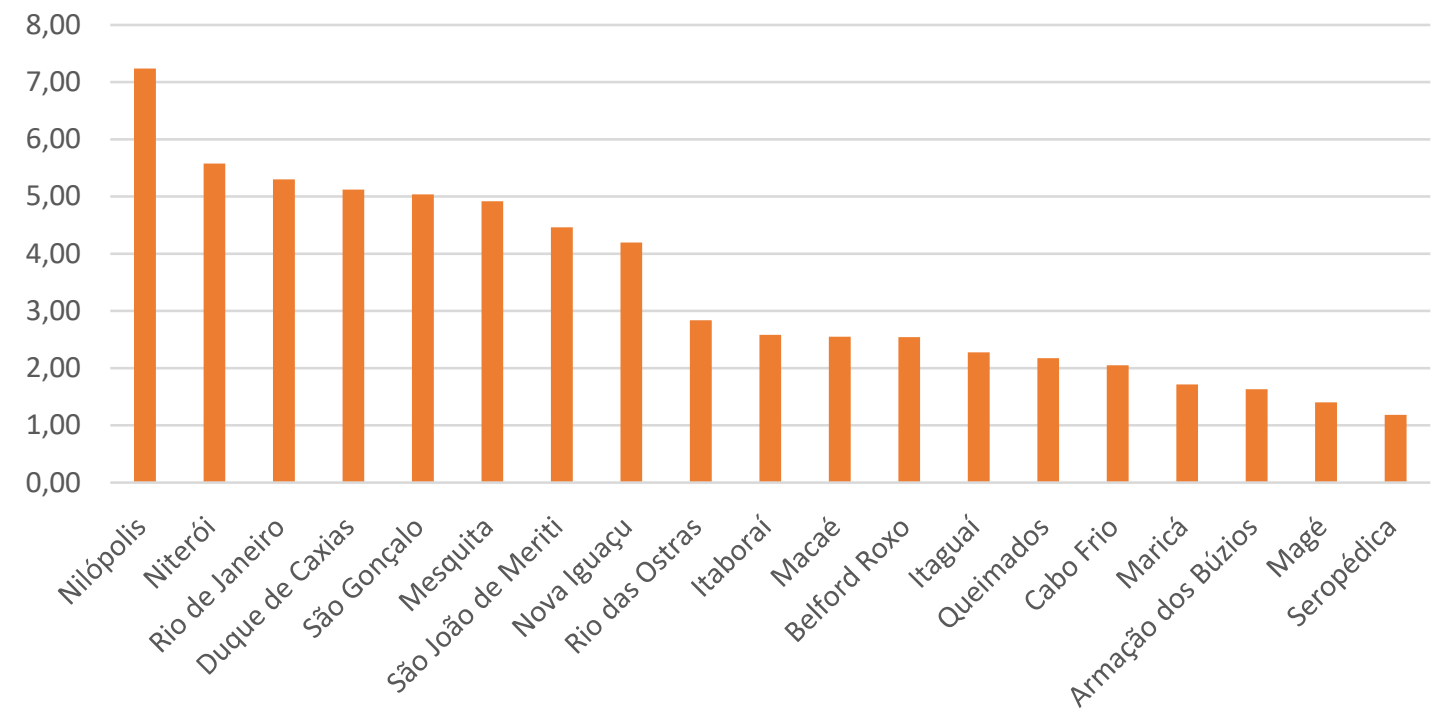

Source: ISP/RJ (2020).

The municipalities of Armação dos Búzios, Cabo Frio, Macaé and Rio das Ostras are the ones located outside the Metropolitan Region that stand out for the occurrence of robbery. In other words, concerning the Dimension Robbery, 15 of the 19 municipalities above average are in the Metropolitan Region.

Graph 2 shows the municipalities of the State of Rio de Janeiro that are above the average in relation to thefts per thousand inhabitants. 


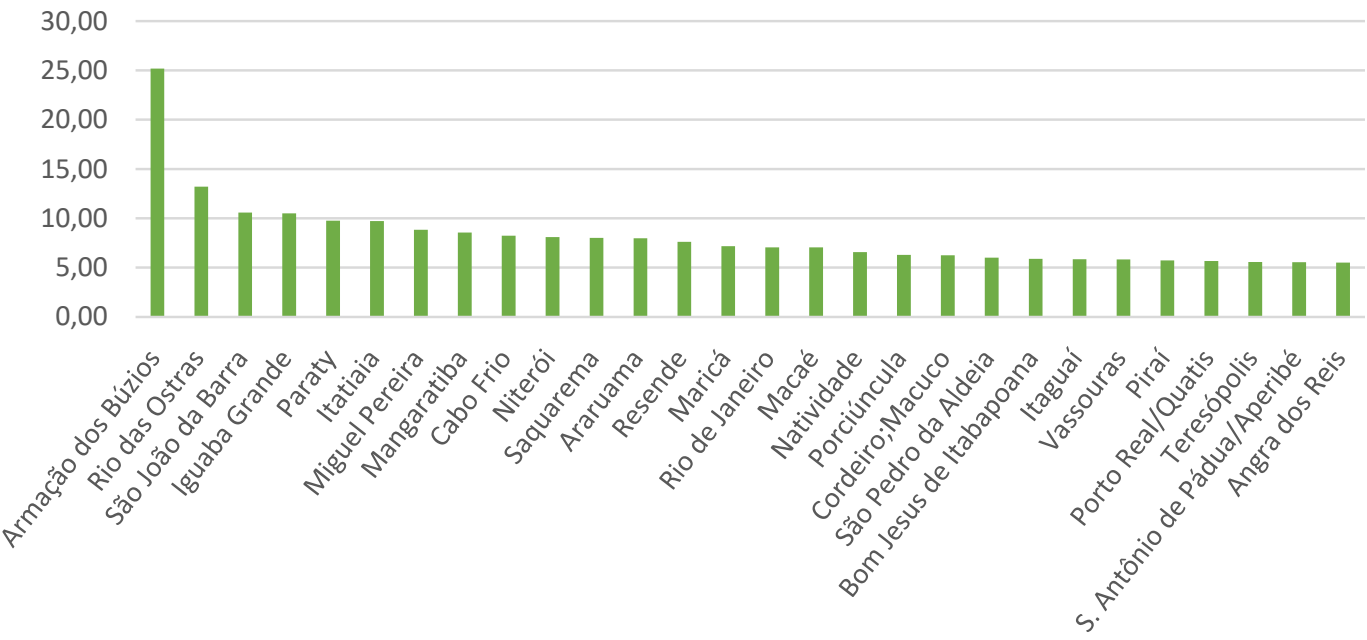

Source: ISP/RJ (2020).

In the Dimension Theft, Armação dos Búzios stands out from the other municipalities, presenting an average score equivalent to twice the second place. In relation to Theft, 28 municipalities are above average and only four of these are in the Metropolitan Region: Itaguaí, Maricá, Niterói, and Rio de Janeiro.

As for the Drugs Dimension, the municipalities that are above the average score of records per thousand inhabitants show a differentiated profile, as shown in Graph 3. The Municipality of Itatiaia presents an average score equivalent to almost 3 times that of Miracema, the second place.

\section{GRAPH 3 MUNICIPALITIES OF THE STATE OF RIO DE JANEIRO WITH DRUGS ABOVE AVERAGE}

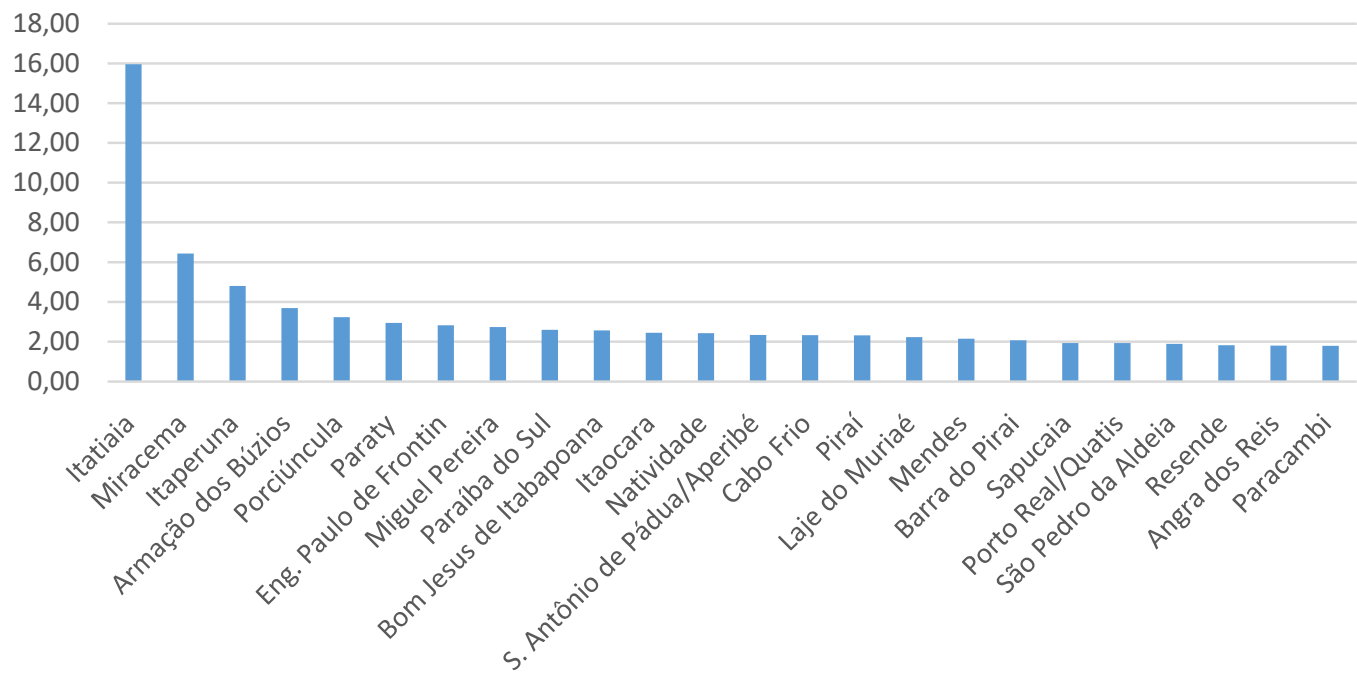

Source: ISP/RJ (2020). 
Another peculiarity of the Drugs Dimension is that of the 24 municipalities that exceed the average score of the State, only one is in the Metropolitan Region, the municipality of Paracambi.

The Person Dimension, related to offenses against the person, is the one with the most homogeneous pattern, as shown in Graph 4. Armação dos Búzios is the municipality with the highest average score per thousand inhabitants, standing out from the second place, Miguel Pereira. The other municipalities do not present any notable differences between them.

\section{GRAPH 4 MUNICIPALITIES OF THE STATE OF RIO DE JANEIRO WITH PERSON ABOVE THE AVERAGE}

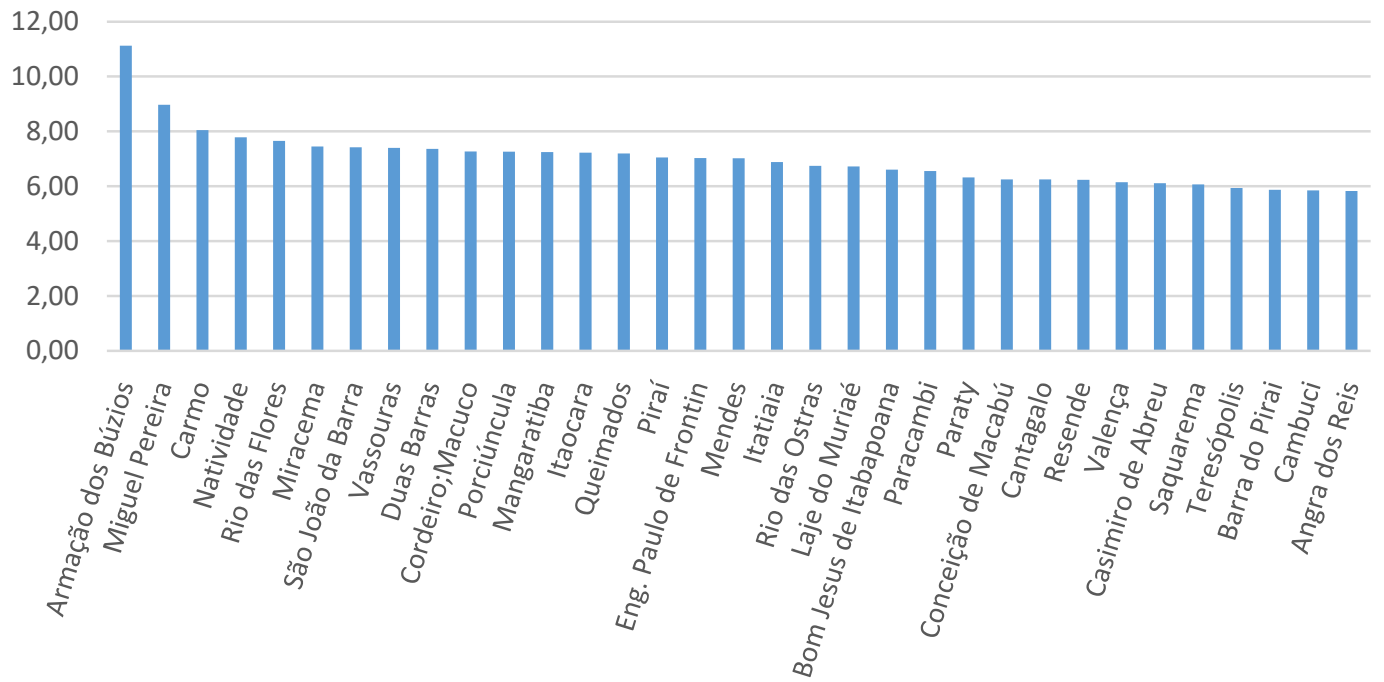

Source: ISP/RJ (2020)

In the Person Dimension, of the 34 municipalities that are above the average, only 2 are in the Metropolitan Region: Paracambi and Queimados. Person is the dimension with the largest number of municipalities above the average and is the most spatially distributed dimension.

Despite the highlights observed in the previous analysis, the municipalities of the State of Rio de Janeiro do not show a clear pattern of crime concentration, as demonstrated in Table 8.

\begin{tabular}{lcccc} 
& ROBBERY & THEFT & DRUG & PERSON \\
\hline ROBBERY & 1 & & & \\
THEFT & 0.2360 & 1 & & \\
DRUG & -0.3488 & 0.4918 & 1 & 1 \\
PERSON & 0.1600 & 0.5635 & 0.1230 & 1
\end{tabular}

Source: Elaborated by the authors. 
All estimates in Table 8 present level of significance below 1\%. The highest Spearman correlation coefficient occurs between Thefts and crimes against the Person.

The negative correlation between Thefts and Drug-related crimes is intriguing because it suggests that one criminal activity could replace the other. In fact, these two types of crime could be being replaced by each other, as both generally do not involve violence against the person, as is the case with Robbery and the Person.

In summary, the correlation analysis shows that the positions in the ordinal scales are not strongly associated and that they can even appear inverted.

\subsection{Granger's Causality Analysis}

Granger's causality analysis involving the four dimensions of crime in the municipalities of the State of Rio de Janeiro shows significance level below $1 \%$ up to the tenth lag. This sole fact clearly shows that the dynamic effects between the dimensions of crime are strong and persist over time.

The four dimensions of crime, arranged in pairs, result in 12 possibilities. As the analysis extends over 10 lags, there are 120 possibilities, of which 32 reach a level of significance below $1 \%$. The relevant pairs appear in Table 9.

\section{TABLE 9 RESULTS OF GRANGER CAUSALITY TESTS WITH A SIGNIFICANCE LEVEL BELOW 1\%}

\begin{tabular}{|c|c|c|c|}
\hline Null hypothesis & N. observ. & F statistic & Signif. level \\
\hline \multicolumn{4}{|c|}{$1 \mathrm{lag}$} \\
\hline THEFT does not Granger Cause PERSON & 1,110 & 25.1270 & $6.0 \mathrm{E}-07$ \\
\hline ROBBERY does not Granger Cause PERSON & & 8.23364 & 0.0042 \\
\hline \multicolumn{4}{|c|}{2 lags } \\
\hline THEFT does not Granger Cause PERSON & 1,036 & 8.22950 & 0.0003 \\
\hline \multicolumn{4}{|c|}{3 lags } \\
\hline THEFT does not Granger Cause PERSON & 962 & 4.08347 & 0.0068 \\
\hline PERSON does not Granger Cause THEFT & & 6.80394 & 0.0002 \\
\hline \multicolumn{4}{|c|}{4 lags } \\
\hline DRUGS does not Granger Cause THEFT & 888 & 3.82268 & 0.0043 \\
\hline PERSON does not Granger Cause THEFT & & 6.94950 & 2.0E-05 \\
\hline \multicolumn{4}{|c|}{5 lags } \\
\hline DRUGS does not Granger Cause THEFT & 814 & 3.60497 & 0.0031 \\
\hline PERSON does not Granger Cause THEFT & & 5.51603 & 5.0E-05 \\
\hline
\end{tabular}


RAP | Criminality in the municipalities of the State of Rio de Janeiro: in search of its essence and its dynamics

\begin{tabular}{|c|c|c|c|}
\hline Null hypothesis & N. observ. & F statistic & Signif. level \\
\hline \multicolumn{4}{|c|}{6 lags } \\
\hline DRUGS does not Granger Cause THEFT & 740 & 3.47394 & 0.0022 \\
\hline PERSON does not Granger Cause DRUGS & & 2.96562 & 0.0072 \\
\hline PERSON does not Granger Cause THEFT & & 5.80671 & $6.0 \mathrm{E}-06$ \\
\hline ROBBERY does not Granger Cause THEFT & & 3.50985 & 0.0020 \\
\hline ROBBERY does not Granger Cause PERSON & & 3.34977 & 0.0029 \\
\hline \multicolumn{4}{|c|}{7 lags } \\
\hline DRUGS does not Granger Cause THEFT & 666 & 3.36436 & 0.0016 \\
\hline PERSON does not Granger Cause THEFT & & 5.83494 & $1.0 \mathrm{E}-06$ \\
\hline ROBBERY does not Granger Cause THEFT & & 3.29897 & 0.0019 \\
\hline ROBBERY does not Granger Cause PERSON & & 3.57584 & 0.0009 \\
\hline \multicolumn{4}{|c|}{8 lags } \\
\hline DRUGS does not Granger Cause THEFT & 592 & 3.14877 & 0.0017 \\
\hline PERSON does not Granger Cause THEFT & & 7.22192 & 4.0E-09 \\
\hline ROBBERY does not Granger Cause THEFT & & 3.38525 & 0.0008 \\
\hline THEFT does not Granger Cause ROBBERY & & 2.76767 & 0.0052 \\
\hline ROBBERY does not Granger Cause PERSON & & 3.23612 & 0.0013 \\
\hline PERSON does not Granger Cause ROBBERY & & 2.56266 & 0.0094 \\
\hline \multicolumn{4}{|c|}{9 lags } \\
\hline THEFT does not Granger Cause DRUGS & 518 & 3.41409 & 0.0004 \\
\hline DRUGS does not Granger Cause THEFT & & 3.46268 & 0.0004 \\
\hline PERSON does not Granger Cause THEFT & & 5.80302 & $1.0 \mathrm{E}-07$ \\
\hline ROBBERY does not Granger Cause THEFT & & 2.86784 & 0.0026 \\
\hline ROBBERY does not Granger Cause PERSON & & 2.70583 & 0.0044 \\
\hline \multicolumn{4}{|c|}{10 lags } \\
\hline THEFT does not Granger Cause DRUGS & 444 & 2.52325 & 0.0059 \\
\hline DRUGS does not Granger Cause THEFT & & 3.09022 & 0.0008 \\
\hline PERSON does not Granger Cause THEFT & & 4.08975 & $2.0 \mathrm{E}-05$ \\
\hline
\end{tabular}

Source: Elaborated by the authors.

Figure 1 provides a visualization of the significant interrelations shown in Table 9. 
FIGURE 1 DYNAMIC EFFECTS BETWEEN THE DIMENSIONS OF CRIME IN THE MUNICIPALITIES OF THE STATE OF RIO DE JANEIRO

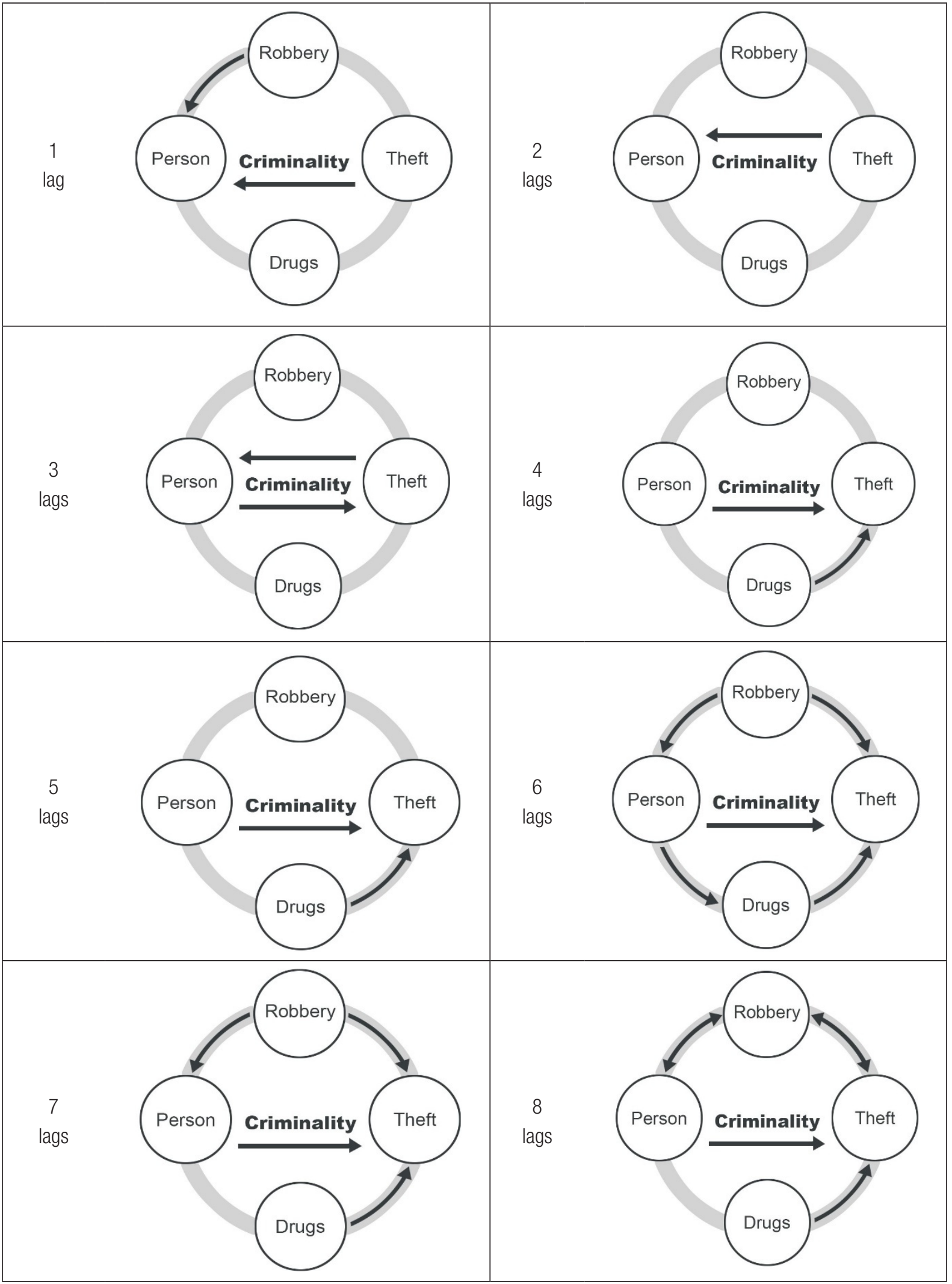

Continue 


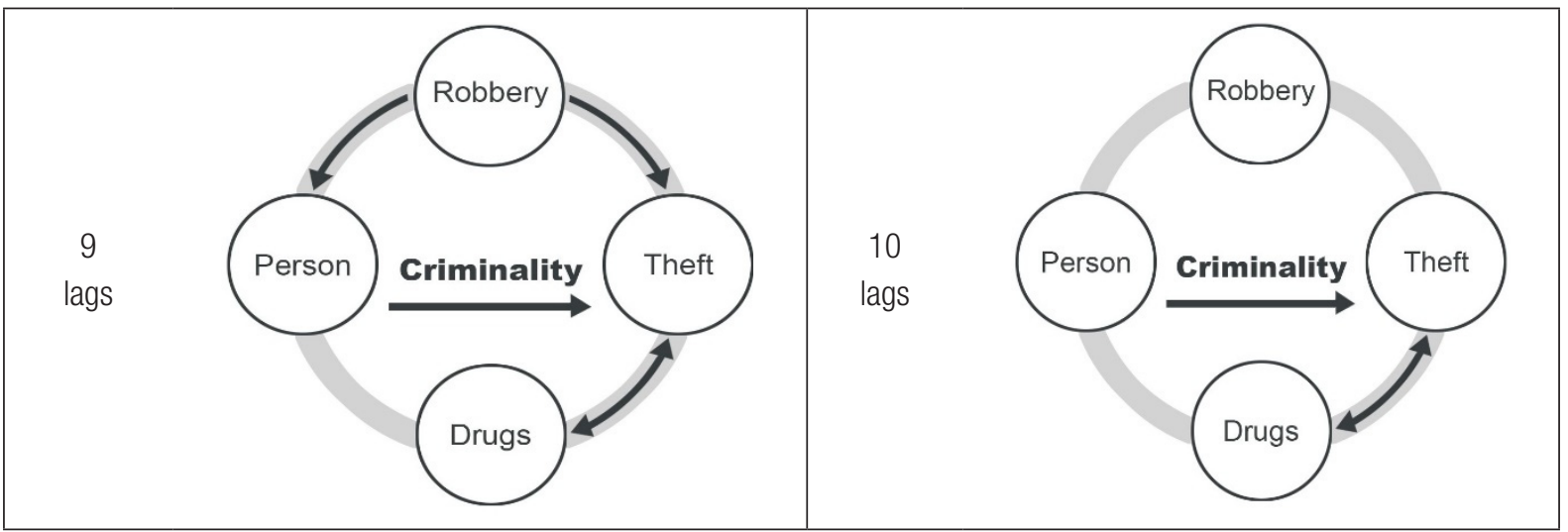

Source: Elaborated by the authors.

Table 9 and Figure 1 show mutual intertemporal influences between the four dimensions of crime, expressed as annual occurrences per thousand inhabitants. The interdependence over time brought to light by Granger's Causality Analysis goes in the same direction as the previous PCA results. Both indicate that the four dimensions are interconnected.

Granger's simultaneous or bilateral causalities occur in the following cases:

- THEFT and PERSON, at the third lag

- PERSON and ROBBERY, at the eighth lag

- THEFT and ROBBERY, at the eighth lag

- DRUGS and THEFT, at the ninth and tenth lags

The weakest temporal interrelationship occurs between crimes against the Person and crimes related to Drugs. Despite that, with six lags, we found statistical evidence to reject the null hypothesis that the level of the Person Dimension in previous years does not contribute to explain the current level of the Drugs Dimension. All other pairs of dimensions show to relate more closely.

Table 10 contains the frequencies of Granger-causes between the dimensions of crime in the municipalities of the State of Rio de Janeiro.

\section{TABLE 10 FREQUENCY OF REJECTION OF THE NULL HYPOTHESIS}

\begin{tabular}{lccc}
\multicolumn{1}{c}{ Granger Causality } & Frequency & Relative Freq. & Accum. \\
\hline 1. PERSON does not Granger Cause THEFT & 8 & 25.0 & 25.0 \\
\hline 2. DRUGS does not Granger Cause THEFT & 7 & 21.9 & 46.9 \\
3. ROBBERY does not Granger Cause PERSON & 5 & 15.6 & 62.5 \\
4. ROBBERY does not Granger Cause THEFT & 4 & 12.5 & 75.0 \\
5. THEFT does not Granger Cause PERSON & 3 & 9.4 & 84.4 \\
\hline
\end{tabular}




\begin{tabular}{lccc}
\multicolumn{1}{c}{ Granger Causality } & Frequency & Relative Freq. & Accum. \\
\hline 6. THEFT does not Granger Cause DRUGS & 2 & 6.3 & 90.7 \\
\hline 7. PERSON does not Granger Cause DRUGS & 1 & 3.1 & 93.8 \\
8. THEFT does not Granger Cause ROBBERY & 1 & 3.1 & 96.9 \\
9. PERSON does not Granger Cause ROBBERY & 1 & 3.1 & 100.0 \\
Total & 32 & 100.0 &.-- \\
\hline
\end{tabular}

Source: Elaborated by the authors.

In Table 10 the predominant Granger causality involves the Person and Theft dimensions and represents $25 \%$ of all cases of rejection of the null hypothesis. We reject the null hypothesis that Person does not Granger-cause Theft at the 1\% significance level in 8 out of 10 relevant lags. This result is surprising because Theft does not involve violence, and its connection with Person should be remote. This evidence contradicts the belief that crimes of Theft, since they characterize as offenses exclusively against property, without violence, would disconnect from crimes against the Person. In fact, the level of crimes against the Person in previous years appear to be relevant to explain the current level of Theft in the municipalities of the State of Rio de Janeiro.

By examining the variables in the three closely related dimensions, Robbery, Theft, and Person (Table 4), we perceive that: (1) Theft and Robbery present six relevant variables in common; (2) Person presents no variable in common with Robbery; and (3) Person presents two variables in common with Theft. The variable Intentional murder loads more on Theft than Robbery. The variables Theft passers-by, and Swindle load more on Robbery than Theft. These unexpected findings indicate that the data do not allow satisfactorily separating the dimensions of Theft and Robbery, probably due to confusion in the data records.

Granger's second most frequent causality, involving Drugs and Theft, which represents $21.9 \%$ of the significant causalities and occurs in 7 of the 10 lags, goes in the same direction. This evidence is remarkable in view of the general belief that illegal drug-related activities do not relate to other types of crime, that is, that crimes related to drugs would occur in a segregated manner, with their own dynamics. The results point in the opposite direction, showing that activities related to illegal drugs in previous years contribute to explain the current level of thefts. So, in view of the previous finding that the dimensions of Robbery and Theft are not well distinct in the data, we conclude that Drugs also has important connections with the Robbery dimension.

Only in the third position, the Granger's causality involving Robbery and crimes against the Person appears. The Brazilian Penal Code typifies the crime of robbery in its article 157, as follows:

Art. 157 - To remove someone else's movable thing, for himself (herself) or for others, by means of serious threat or violence to the person, or after having, by any means, reduced the person to the impossibility of resistance.

The crime of robbery, as defined, always involves violence against the person, since threatening someone or reducing him (her) to the impossibility of resistance also constitutes violence. Therefore, 
it seems surprising that the causality in Granger's sense between Robbery and crimes against the Person does not stand out in the first position, because environments subject to Robbery would be more likely to present crimes against the Person. The data do not support this. Again, as the data do not allow to safely separate the dimensions of Theft and Robbery, this result comes to be possible.

The fourth causality in the sense of Granger involves Robbery and Theft, accounting for $12.5 \%$ of the significant relationships and occurring in four of 10 relevant lags. The Brazilian Penal Code defines the crime of theft in its article 155 as "subtracting, for him (her) or for others, someone else's mobile thing". Thus, theft directs exclusively against the victim's belongings, not involving violence against the person. Environments subject to incidence of Robbery would be prone to incidence of Theft. This result goes against common sense. In general, people believe that theft practitioners could become violent, committing robbery, and not the other way around. However, this result is restricted to the impossibility of clearly separating these two dimensions from the data.

The causal relationship in the Granger's sense between Theft and crimes against the Person occupies the fifth position, represents $9.4 \%$ of the significant interrelationships and occurs in three of the 10 lags. Again, our results indicate no support to the assumption that crimes solely against property do not create a favourable environment for crimes against the person.

The Theory of Institutional Choice, as well as the Theory of Broken Windows, show that the dimensions of crime, once present, have effects on one another over time, corroborating the idea that rupture of ethical and moral standards opens space for crime to arise, diversify, and increase in society. In brief, the criminal types are not specialized and independent.

To further clarify the dynamics involving the dimensions of crime in the municipalities of the State of Rio de Janeiro, Table 11 contains the frequencies with which these dimensions occur as a cause or as a result in the sense of Granger.

\section{TABLE 11 THE DIMENSIONS OF CRIME AS CAUSES AND RESULTS IN THE SENSE OF GRANGER}

$\begin{array}{lcccc}\text { Dimension } & \text { Cause } & \text { Effect } & \text { Total } & \text { Type } \\ \text { Robbery } & 9 & 2 & 11 & \text { Gateway }^{*} \\ \text { Theft } & 6 & 19 & 25 & \text { Advanced form* }^{*} \\ \text { Drugs } & 7 & 3 & 10 & \text { Gateway } \\ \text { Person } & 10 & 8 & 18 & \text { Hybrid } \\ \text { Total } & 32 & 32 & 64 & -.-\end{array}$

Note: ${ }^{*}$ Theft and Robbery dimensions could not be clearly separated in the data.

Source: Elaborated by the authors.

The Robbery dimension stands 9 times as a Granger cause and only 2 times as an effect of the other three dimensions. This means that the Robbery dimension would predominantly be a gateway to the world of crime, appearing in advance in environments where other dimensions will become 
significant. The opposite would occur in relation to the Theft dimension that generally follows other criminal modalities. The Theft dimension is precedent in six intertemporal relationships and follows the other dimensions in 19 of these relationships.

However, the previous analysis is restricted to the fact that the used data do not allow clear separation between Theft and Robbery dimensions. Even though, if we consider these two dimensions together, Robbery-Theft will appear 10 times as Granger-cause and 16 times as effect. In conjunction, crimes against property are predominantly consequences of a dilacerated social environment.

Still according to Table 11, the dimension related to Drugs precedes the other 3 dimensions in 7 intertemporal relations and follows the incidence of the others in only 3, showing that it is also predominantly a gateway to other criminal modalities. The dimension related to crimes against the Person has a balance in temporal interrelationships with the other dimensions, with 10 interrelationships in which it appears as a precedent and 8 in which it appears as a consequent.

Granger's Causality Analysis also allows identifying the most fragile intertemporal relationships between the four dimensions of crime. In this sense, it is not possible to reject the null hypothesis that Drugs dimension is not cause for Person dimension in any of the 10 lags, that is, the data do not offer any evidence that drug-related crimes in previous periods contribute to explain the current level of crimes against the person.

According to the Theory of Institutional Choice, the individuals inserted in a given institutional framework of criminality make their choices in accordance with its rules and standards and become susceptible to various types of crimes; while according to the Theory of Broken Windows, the criminal environment works as an invitation and incentive to the practice of crimes of all kinds. Our results show that, in general, criminal activities are interchangeable over time, make clear the intertwined nature of the social phenomenon of crime, and are in accordance with the two referred theories.

The most serious implication of these results concerns the error of public policies focused on the segmentation of crime and based on violent repression. The municipal statistics of the State of Rio de Janeiro for the two decades of this century show that crime is a social phenomenon whose dimensions are not well defined and are interchangeable over time. Consequently, public policies based on the traditional segmentation of crime and based on the war on crime are necessarily topical and of doubtful effectiveness.

\section{CONCLUSION}

The analysis of crime in the municipalities of the State of Rio de Janeiro, through the Principal Component Analysis, shows four dimensions: Robbery, Theft, crimes related to Drugs and crimes against the Person. Rather than being independent, these dimensions intertwine, presenting significant cross-effects between them over time, as detected through the Granger Causality Analysis. Unfortunately, we could not clearly separate the Theft and Robbery dimensions, indicating possible confusion in the crime records.

When we spatially refer the four dimensions, the result is a very uneven distribution among the municipalities of the State of Rio de Janeiro, except for crimes against the Person. We find no indication of spatial concentration of crime. Furthermore, the municipalities that present a prominent position 
in one dimension of crime do not necessarily stand out in the others. We even find an inverse ordinal correlation between the scales of Robbery and Drugs.

The Granger's Causality Analysis clarifies those apparently contradictory results. Such analysis makes evident an intense intertemporal interaction between the dimensions of crime. In fact, our results indicate that the dimensions of crime form an intricate network of intertemporal effects, constituting a vigorous dynamic.

However, our results are not in accordance with the security policy applied in the State of Rio de Janeiro, throughout Brazil and in many countries. The war on crime, based on violent repression directed at society's enemies, is far from what our results recommend. Such security policy in addition to be ineffective has a particularly undesirable characteristic, since being impossible to distinguish criminals from non-criminals, every individual is potentially an enemy. The result is a violent repressive action based on stereotypes and prejudices that, unfortunately, remind Lombroso.

As if that were not enough, the battles of this pseudo-war occur in the same territory in which the criminals and non-criminals live and, therefore, the number of victims and loss of property is prohibitive. Still worse, all people living in areas occupied by the war on crime have no choice but to collaborate with one side. Often, under threat and violence.

Violently repressing, showing the war on crime in the media and incarcerating large contingents have not brought good results. While the authorities insist on this policy, crime has been increasing in the state of Rio de Janeiro and throughout Brazil.

According to the theories discussed here, the high level of crime is the result of the formation of a degraded institutional environment. In this environment, people who decide and act have low self-esteem, have not had the opportunity to educate themselves and enter the job market. Therefore, an effective public policy must act primarily on the institutional environment of crime. Fixing the broken windows requires offering individuals the opportunity for education and employment to boost their self-esteem.

In summary, our results are in line with the Theory of Institutional Choice and the Theory of Broken Windows and allow us to infer that the increasingly violent repression must be set aside because:

- Despite the repercussions in the media, it does not reach the causes of the crime.

- Does not improve the institutional environment and does not repair broken windows.

- It costs many lives and causes a lot of suffering and material damage.

A close look realizes that high crime is just one of the ills of societies that, for decades, have been unable to care for children and young people and that, consequently, have, over time, their institutional environment increasingly run-down, with broken windows and incentives for delinquency of all kinds, everywhere.

Therefore, a real security policy should:

- Break the vicious circle, guaranteeing quality school and minimum conditions of dignity for large sectors of the population. 
RAP | Criminality in the municipalities of the State of Rio de Janeiro: in search of its essence and its dynamics

- Emphasize the insertion of criminals in the institutional environment of the State and encourage everyone to remain under State institutions.

Finally, we conclude that authorities need technical and scientific support to design innovative and more ample public security policies. The insistence on violent repression points to increasing costs for society and worsening of the situation, as we have been observing. 


\section{REFERENCES}

Baltagi, B. H. (2011) Econometrics (5a ed.). London, UK: Springer.

Brasil 247. (2020). Uma Teoria do Crime que Merece Reflexão. Retrieved from https://www. brasil247.com/pt/247/revista_oasis/116409/JanelasQuebradas-Uma-teoria-do-crime-que-merecereflex\%C3\%A3o.htm

Cano, I., \& Duarte, T. (2012). "No sapatinho": a evolução das milícias no Rio de Janeiro [20082011]. Rio de Janeiro, RJ: Fundação Heinrich Böll. Retrieved from https://br.boell.org/sites/default/ files/no_sapatinho_lav_hbs1_1.pdf

Clemente, A. (1989). Pesquisas de Variáveis Múltiplas. Curitiba, PR: Scientia et Labor.

Clemente, A., \& Welters, A. (2007). Reflexões sobre o modelo original da Economia do Crime. Revista de Economia, 33(2), 139-157.

Collier, M. W. (2002). Explaining corruption: an institutional choice approach. Crime, Law and Social Change, 38(1), 1-32.

Departamento Penitenciário Nacional. (2020). Dados sobre população carcerária do Brasil. Retrieved from https://www.gov.br/pt-br/noticias/justicae-seguranca/2020/02/dados-sobre-populacaocarceraria-do-brasil-sao-atualizados

Foucault, M. (1987). Vigiar e Punir: nascimento da prisão (27a ed.). Petrópolis, RJ: Vozes.

Gujarati, D. N. (2007). Basic Econometrics (4a ed.). Toronto, Canada: McGraw Hill.

Hair, J. F., Jr. (2009). Análise multivariada de dados (6a ed.). Porto Alegre, RS: Bookman.

Instituto Brasileiro de Geografia e Estatística. (2019). População residente estimada. Retrieved from https:// sidra.ibge.gov.br/tabela/6579

Jensen, A. R. (1969). How Much Can We Boost IQ and Scholastic Achievement? Harvard Educational Review, 39(1), 1-123.
Judge, W. Q., McNatt, D. B., \& Xu, W. (2011). The antecedents and effects of national corruption: a meta-analysis. Journal of World Business, 46(1), 93-103.

Kelling, G. L., \& Wilson, J. Q. (1982). Broken Windows: The police and neighborhood safety. The Atlantic. Retrieved from https://www. theatlantic.com/magazine/archive/1982/03/brokenwindows/304465/

Leite, M. S. P. (2012), Da 'metáfora da guerra' ao projeto de 'pacificação': favelas e políticas de segurança pública no Rio de Janeiro. Revista Brasileira de Segurança Pública, 6(2), 374-389. Retrieved from https://aprender.ead.unb.br/pluginfile.php/22591/ mod_forum/attachment/27462/Leite(2012).pdf

LeSage, J. P. (1999). Applied Econometrics using MATLAB. Toledo, OH: University of Toledo.

Lombroso, C. (2007). O Homem Delinquente. São Paulo, SP: Ícone.

Maia, K. S., \& Zamora, M. H. N. (2018). O Brasil e a Lógica racial: do branqueamento à produção de subjetividade do racismo. Psicologia Clínica, 30(2), 265-286.

Monteiro, J., Fagundes, E., \& Guerra, J. (2020). Letalidade policial e criminalidade violenta. Revista de Administração Pública, 54(6), 1772-1783. Retrieved from https://doi.org/10.1590/0034761220200061

Silva, M. L. (2017). População-sacer e democracia racial no Brasil. Revista Sociedade e Estado, 32(3), 593-620.

Souza, L. A. F., \& Serra, C. H. A. (2020). Quando o Estado de exceção se torna permanente: reflexões sobre a militarização da segurança pública no Brasil. Tempo Social, 32(2), 205-227. Retrieved from https:// doi.org/10.11606/0103-2070.ts.2020.158668

Wachelke, J., \& Prado, A. M. (2017). A ideologia do jeitinho brasileiro. Psicologia e Saber Social, 6(2), 146-162, 2017. 


\section{Ademir Clemente}

https://orcid.org/0000-0002-3998-6263

D.Sc. from Universidade Federal do Rio de Janeiro (UFRJ).E-mail: ademirclemente@gmail.com

\section{Leonel Toshio Clemente}

https://orcid.org/0000-0001-8032-1530

Professor at the Departamento de Economia e Relações Internacionais from Universidade Federal do Rio Grande do Sul (UFRGS). E-mail: leoneltclemente@gmail.com

\section{Artur Kendi Clemente}

https://orcid.org/0000-0002-4234-5985

Bachelor of Economics from Universidade Federal do Paraná (UFPR). E-mail: akenji47@gmail.com 